\title{
Visitor Profile Of Cuenca Religious Music Week
}

Juan-Antonio Mondéjar-Jiménez, Ph.D., University of Castilla-La Mancha, Spain

María Cordente-Rodríguez, University of Castilla-La Mancha, Spain

Juan-Carlos Gázquez-Abad, Ph.D., University of Almería, Spain

Esteban Pérez-Calderón, Ph.D., University of Extremadura, Spain

Patricia Milanés-Montero, Ph.D., University of Extremadura, Spain

\begin{abstract}
Religious Music Week in Cuenca is the fourth oldest music festival in Spain, involved in orchestras, choirs and performers of international stature and prestige that interpret various compositions of sacred music. Religious Music Week in Cuenca is declared a Fiesta of International Tourist Interest, since its inception in 1962, has always retained a strong personality as a result of high musical expertise; it is wonderful geographical location and the enormous wealth of heritage that surrounds it. This festival is writing a new chapter in the annals of religious music. Their long tradition has set the standard in Spain, which allows comparison with other festivals in Europe. In the present study is to characterize the profile of the visitor from the 48th through a questionnaire administered to attendees of the event, in the same show basic characteristics of visitors, taking a special interest in the economic impact is Cuenca city for the celebration of this event.
\end{abstract}

Keywords: Tourist attractions, events, impacts of tourism.

\section{INTRODUCTION}

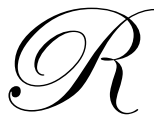

eligious Music Week in Cuenca is the fourth oldest music festival of Spain. It is a benchmark among religious music festivals, as its long tradition has set the standard in Spain, and allows it to compare with the other European festivals.

Religious Music Week in Cuenca is declared a Feast of International Tourist Interest; since its inception in 1962, has always maintained a strong personality as result of high musical expertise, its wonderful geographical location and the enormous heritage wealth that surrounds it. Also, it is a member of the European Festivals Association (EFA) since 1986, with over 100 performing arts festivals from 38 countries.

In 2009 there was the celebration of the 48th edition of the Religious Music Week in the city of Cuenca, held from April 4 to April 12, 2009 (Easter Sunday), coinciding with the celebrations of the Easter Week, declared of Cultural Interest.

While the concerts, held a conference on "Literature, mystic, music", dealting mystical literature and its impact on music, with special attention to the work of San Juan de la Cruz. Furthermore, this edition had the premiere of two commissioned works, the recovery of musical heritage (with the restoration of the Gospel Organ of the Cathedral of Cuenca and the presentation of catalog music collection of the Library of the Monastery of Uclés) and the celebration of the anniversaries of Georg Friedrich Haendel (250th anniversary of his death, 1685-1759) and Franz Joseph Haydn (200th anniversary of his death, 1732-1809).

The concerts were held in ten emblematic sites in Cuenca, as the Cathedral, the Auditorium Theatre, Antonio Pérez Foundation and the Church of La Merced. These spaces in the city of Cuenca, declared World Heritage Site, provide architectural beauty at the intense religious spirit. 
The main aim of this study is to determine the impact of the Religious Music Week in the city of Cuenca, in order to develop marketing and communication strategies appropriate to the profile of the attendees. The specific objectives of this project are:

- $\quad$ Knowing the profile of attending at the Religious Music Week in Cuenca.

- $\quad$ To analyze spending by attendees in the city.

- $\quad$ Studying attendees' satisfaction with the festival, to know the weaknesses and try to fix for future editions.

- $\quad$ Knowing the economic impact of this festival on Cuenca.

\section{METHODOLOGY}

\section{Data Collection and Sampling Design}

To achieve the objectives, information was gathered on their own attending the Religious Music Week in Cuenca. Obtaining the information was carried out by direct interviews to those attending the concerts, chosen at random, trying to cover the widest possible range. The data collection work was done in 13 of the 25 concerts scheduled, at different times of the concerts: at the entrance, at breaks and out of them.

As result, 180 questionnaires were obtained, with whom, and for around 10,000 attendees, a sample size of 180 provides results with an initial error of $\pm 7.39 \%$, providing a confidence level of $95 \%$ for an estimated variable with two categories equally likely $(\mathrm{p}=\mathrm{q}=0.5)$. Table 1 lists the most important characteristics of the sample design and data collection.

Table 1: Factsheet

\begin{tabular}{|l|l|}
\hline Population & Attendees at the $48^{\text {th }}$ Religious Music Week in Cuenca \\
\hline Methodology & Personal interviews by structured questionnaire \\
\hline Sample Size & 180 valid questionnaires \\
\hline Sampling Error & $\pm 7,39 \%$ \\
\hline Confidence Level & $95 \%$ ( $\mathrm{p}=\mathrm{q}=0,5)$ \\
\hline Date of Data Collection & From 4 to April 12,2009 \\
\hline
\end{tabular}

\section{RESULTS}

\section{Socio-Demographic Analysis}

The attendee' profile at the Religious Music Week in Cuenca, has the following main features (Table 2):

- $\quad$ Almost equal distribution between women and men, 51.67\% and 48.33\% respectively.

- $\quad$ Middle age (the most common age group is 45 to 54 years, 35\%) and married status (57.78\%) with university education $(79.44 \%)$ and are worker ( $57.22 \%)$.

- $\quad$ The visitor profile is almost exclusively national, $94.44 \%$.

The origin of the participants in the Religious Music Week is, primarily, the provinces of Cuenca $(34.44 \%)$, Madrid (23.89\%) and Barcelona (6.11\%).

The average monthly income of attendees is above $€ 2,000$, being the most common stretch for $50 \%$ of the participants surveyed. The observed trend is that the higher the income, the higher the percentage assistants who are in that income level. 


\title{
Descriptive Analysis of attendance Religious Music Week in Cuenca
}

\author{
- $\quad$ Experience in the Religious Music Week
}

Around $65 \%$ of the attendees have attended prior to the Religious Music Week in Cuenca, compared with $35 \%$ attending for the first time. Of previous attendees, the average of previous experience is 10 editions. And it highlights the fact that $4.35 \%$ has attended all the editions. This finding demonstrates the existence of a high fidelity by the attendees.

\section{- $\quad$ Attendance at Religious Music Week}

The $87.22 \%$ attend the concerts organized by the Religious Music Week together, compared with $12.22 \%$ attend alone. International attendees always come together.

The average number of concerts to attend is expected is 5.41 per person. However, only $16.11 \%$ of the participants has full pass.

\section{- $\quad$ Expected length of stay}

Given that $33.89 \%$ of the participants surveyed live in Cuenca, the average stay of foreigners was 3.02 days, a relatively large number, where the percentage of most frequent stays is four or more days $(30,56 \%)$ and the least common is to stay for only one day $(7.78 \%)$. This extended stay is made possible by the coincidence of the celebration of the Religious Music Week with the Easter Week, which allows participants to have more holidays.

\section{- Type of accommodation}

In reference to the type of accommodation, the majority, 52.38\%, elected a hotel accommodation, being four-star hotels the most demanded category, followed by three and two stars. The second type of accommodation chosen is hostel or pension with a $25.71 \%$ and, thirdly, is accommodated in the homes of friends or relatives $(8.57 \%)$.

\section{- $\quad$ Reason or person who encouraged him to come}

The main reason that encouraged him to attend the Religious Music Week in Cuenca was previous experience (29.44\%), reinforcing the idea of high fidelity of those attending the festival, followed by the mass media ( $26.11 \%$ ), recommendations from friends/family (25\%) and, in fourth place, with 10\%, for working (critical journalists, musicians, etc.).

It is remarkable that only a $1.67 \%$ attends the Religious Music Week drawn mainly by the visit to the city of Cuenca.

- $\quad$ Principal activity in the stay in Cuenca

The main activity developed by participants during their stay in Cuenca is, mostly, from attendance Religious Music Week (79.23\% of cases), and, secondly, a visit to the city of Cuenca (10.77\% of the attendees).

\section{- $\quad$ Celebration Date}

Regarding the timing of the Religious Music Week, the $57.78 \%$ would attend regardless of the date of signing, symbol of his fidelity to the event. While, $21.67 \%$ would attend only if it coincides with the date of Easter Week and 20\% attend only if performed on holidays. 
- $\quad$ Opinion about the Religious Music Week in Cuenca

The average opinion that the assistance granted to the Religious Music Week in Cuenca, is 8.59 over 10 points, an extremely high califfication. This assessment varies depending on experience: the average score is higher when they have previously attended the Religious Music Week in Cuenca, when they do the first time.

\section{Expenditure Structure}

- $\quad$ Overall Budget

Analyzing the overall budget for attending the Religious Music Week throughout their stay in Cuenca, and considering all the cost items (transport, accommodation, meals, tickets, etc..), we obtain an average budget of $€$ 301.15; as the average length of stay was 3.02 days, it suppose high daily expenditure of $€ 99.72$ per day and per person.

On the other hand, if we analyze the overall budget distinguishing the origin of attendees, the budget amounts to $€ 362.71$ for foreigners and $€ 171.43$ for those living in Cuenca. Also, international attendees have an average overall budget (€ 480) higher than Spaniard (€ 290.24).

- Daily expenditure by service

In general, analyzing the distribution of daily expenditure per attendee in different services, we obtain, in a majority of the sections, the lower spending on the scale and, even, the option of anything stated in many cases the highest frequency.

The most significant expenditure of attendees at the Religious Music Week is restaurents and attendance at concerts. The less important expenditure items are the purchase of gifts, entertainment and accommodation.

\section{- $\quad$ Admission Fee}

The price of tickets for concerts isolated between 20 and 40 euros, except for the three concerts scheduled in the program of the conference "Literature, Mystic, Music", priced at 5 euros.

The $72.78 \%$ of the participants considered that this is the right price, compared to $19.44 \%$ believed that the price is excessive, being the best price more common option among foreigners than among Spaniards. It is remarkable that the $1.67 \%$ reported that the price is low and the quality of the concerts is very high for the price paid by the entrance. These assistants are characterized by having revenues in excess of $€ 2,000$ and university studies. Also, the $11.11 \%$ of attendees has received an invitation.

\section{Influence of the Religious Music Week in the assistant}

The celebration of the Religious Music Week in Cuenca has a major impact on the audience: the $97.78 \%$ of the participants would return to attend the next edition, $100 \%$ of respondents would recommend the festival to other acquaintances, relatives or friends, and $76.67 \%$ of the participants associated the city of Cuenca with the celebration of the Religious Music Week. Also, 100\% of respondents would recommend Cuenca as tourist destination.

\section{ANALYSIS OF ECONOMIC IMPACT}

For economic impact means the effect on production, income and employment associated with investments and current expenditure made by the various agents involved in a particular cultural event, on a certain geographical area in a given period of time. According to Seaman (2003) economic impacts are divided into three groups: direct impacts, indirect and induced. 


\section{Direct Impacts}

Are the costs incurred by the business or cultural institution, holiday or sports to host the event analyzed in different terms (wages, purchases, rentals, program implementation, etc.) in the geographic area of reference and a time period determined.

The direct impact of the Religious Music Week is formed mainly by spending of the Cultural Foundation governing this festival held in lighting, decor, staging, assembly, installation, insurance, leasing, etc., to host the event. The total expenditure amounts to $€ 1,137,600$.

Much of this spending affects local businesses, but no detail can be detailed as their distribution is unknown. While included: artistic expenses (entertainment and training), technical production costs (rent, electricity, sound, stage), hotel and travel expenses, promotion and advertising costs, administrative expenses and management and infrastructure maintenance costs (cleaning).

\section{Indirect Impacts}

It is the spending by visitors or attendees as result of consumption of cultural products, holiday or sports. In the case of the Religious Music Week, are attributable to spending by visitors tourists in accommodation, catering, transportation, shopping, etc. The estimate was obtained from a survey of attendees of the concerts, collecting information on three variables:

- $\quad$ The number of attendees.

The information on the number of attendees can be approximated by the number of localities, which for the 48th edition was in 9796 locations. On this figure applies a coefficient of repetition to reduce duplication of visitors who have come several times to acts of cultural programmation. As result of the survey, we find that the expected average number of concerts is 5.41 per person. Thus, we can estimate a total of 1,811 attendees.

- $\quad$ Average expenditure per attendee.

Analysing the survey, we find that the global average budget available for the entire stay for foreigners is $€$ 362.71 per person and $€ 171.43$ for attendees living in Cuenca.

Of the 1811 estimated participants, $34.44 \%$ reside in Cuenca and $65.56 \%$ are from other provinces and countries. With these figures and the estimated overall budget for each group, gives a figure of total estimated expenditure for stay by total attendance of $€ 537,509$, in every sectors of expenditure (accommodation, restaurants, tickets, entertainment, shopping and other expenses). Of which $€ 116,636$ relate to the collection through ticket sales, and $€ 420,873$ is the fundraising of the event gives local companies engaged in hotel, restaurant, retail, leisure and other facilities.

- $\quad$ The intention to visit.

We seek to assess how the Religious Music Week influence in the intention to visit Cuenca. To do this, the respondent must indicate on the questionnaire, the principal activities during his stay in Cuenca, choosing one of the following options:

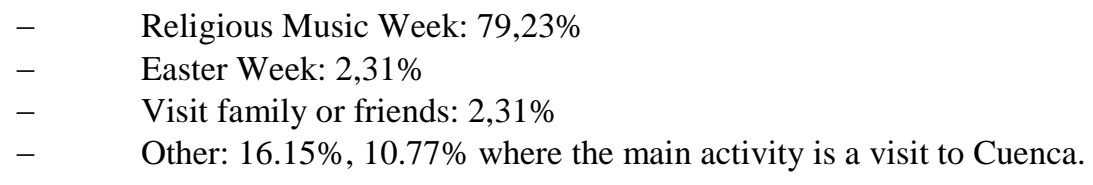

It is also necessary to consider the previous experience with the festival, for $65 \%$ of respondents showing satisfaction with this musical event. 


\section{Induced Impacts}

Are the implications arising from the amount of money derived by direct and indirect impacts, and that spread or expanded for the rest of the economic system, within and outside the space reference. This effect is called multiplier effect. It also impacts on the local economy, through notoriety achieved by municipality in the media, in the dissemination of his image, recognition and promotion of the city.

The distribution of the induced effects, on output and employment, between different economic sectors would be determined by budget allocation, which is unknown in detail, not possible to quantify these effects

\section{CONCLUSIONS}

From the collected information in this study, the main conclusions and recommendations can be summarized as follows:

1. Strong consolidation achieved by the Religious Music Week in Cuenca, in the national and international music scheme. He has done forty-eight editions with great success and has capacity for loyalty to the attendees but also to attract new audiences. Thus, $97.78 \%$ of the participants said they would return next year to the Religious Music Week in Cuenca and nearly $77 \%$ of the participants, associate the city of Cuenca with the celebration of this festival.

2. They are very loyal audience, with high experience in the festival, with significant participation in this edition and with an expected average attendance of 5.41 concerts per person.

3. Only the $16.11 \%$ of the participants have full pass, which highlights the need for adjust the full pass not for the space of celebration, but for days; then, perhaps, the distribution of the full pass during the week of the festival, will lead to the attendee more difficult to fit their free time.

4. Attendees value the festival with an average rating of 8.59 over 10, being higher for those who have attended previously. This is a clear sign of improvement over time, as participants tend to make comparisons over the years prior to assessing the current edition.

5. The most frequent profile among attendees is characterized by middle-aged individuals (45-54 years), mainly with university studies and Spaniard, and with an average monthly income over 2,000€.

6. The average attendees stay is three days, compared with 9 days of the event; a high number, perhaps possible to match your celebration with Easter Week. However, $60 \%$ of the participants said they would attend no matter what was the timing, and $20 \%$ attend only if performed on holidays. These data reflect a certain independence from the festival over Easter Week for $80 \%$ of the participants.

7. The average budget of the attendees for the whole stay, considering all costs (transportation, acommodation, meals, tickets, etc..), is $€ 301.15$. However, the global budget data change considerably if we look separately at the participants living in Cuenca and the foreigners, because of different needs during your stay: thus, the attendee who lives in Cuenca, has an overall budget for the festival of $€ 171.43$ per person, while the figure for the foreigners is $€ 362.71$.

8. International attendees have an average overall budget higher than Spanish participants, $480 €$ and $€ 290.24$ respectively, but the first represent only $5.56 \%$ of total attendees. So, it is necessary and interesting to make further promotion of the festival activities abroad, to attract international attendees.

9. The most significant expenditure for attendees of the Religious Music Week is in restoration and attendance at concerts. And the less important expenditure items are the purchase of gifts and souvenirs / trade, other costs, leisure and acommodation, items of interest to promote among the participants.

10. The economic impact of the Religious Music Week is estimated at not less than $€ 1,675,109$ (direct and indirect), of which $32.09 \%$ related to the tourist attraction that causes the festival (indirect effects) and other direct expenditure made by the Cultural Foundation in the implementation of the festival (direct effect). Even if you take into account the induced effects, which have been mentioned in a qualitative way, the final impact would exceed this figure.

Religious Music Week in Cuenca has become a strong tourist attraction for Cuenca, which has led to significant economic effects and has generated a substantial change in the pattern of tourism behavior of visitors. These results largely justify the investment and enhancing the conduct of such events, since there is no doubt that progress is a factor of tourism competitiveness. 


\section{AUTHOR INFORMATION}

Juan-Antonio Mondéjar-Jiménez: PhD and Degree in Business Administration by University of Castilla-La Mancha. Degree in Advanced Studies in Marketing at the same university. Associate Professor in Marketing at Business Department. Faculty of Social Sciences of Cuenca. University of Castilla-La Mancha (Spain). E-mail: JuanAntonio.Mondejar@uclm.es

Research Interest: Consumer behavior, price perception, e-learning and tourism marketing.

María Cordente-Rodríguez: Degree in Business Administration by University of Castilla-La Mancha. Lecturer in Marketing at Business Administration Department. Faculty of Social Sciences of Cuenca. University of Castilla-La Mancha (Spain). E-mail: Maria.Cordente@uclm.es

Research Interest: Tourism marketing, consumer behavior and e-learning.

Juan-Carlos Gázquez-Abad: $\mathrm{PhD}$ and Degree in Business Administration by University of Almería. Associate Professor in Marketing at Business Department. Faculty of Business and Economics, University of Almería (Spain). E-mail: jcgazque@ual.es

Research Interest: Consumer behavior, retailing, sales promotions

Esteban Pérez-Calderón: $\mathrm{PhD}$ and Degree in Business Administration by University of Extremadura. Assistant professor in Accounting at Faculty of Tourism and Business of Cáceres. University of Extremadura (Spain). E-mail: estperez@unex.es

Research Interest: Accounting and tourism.

Patricia Milanés-Montero: PhD and Degree in Business Administration by University of Extremadura. Assistant professor in Accounting at Faculty of Tourism and Business of Cáceres. University of Extremadura (Spain). E-mail: pmilanes@unex.es

Research Interest: Accounting and tourism.

\section{REFERENCES}

1. Devesa, M. (2006): El impacto económico de los festivales culturales: el caso de la Semana Internacional de Cine de Valladolid. Madrid: Iberautor Promociones Culturales S.L.

2. Herrero, L.C. (2004): "Impacto económico de los macrofestivales culturales: reflexiones y resultados", Portal Iberoamericano de Gestión Cultural.

3. Herrero, L.C. (2004): Turismo Cultural e Impacto Económico de Salamanca 2002, Ciudad Europea de la Cultura. Madrid: Civitas.

4. Instituto de Estudios Turísticos (2010): Encuesta de Gasto Turístico (EGATUR 2009). Madrid: Secretaría de Estado de Turismo y Comercio, Ministerio de Industria, Turismo y Comercio.

5. Instituto Nacional de Estadística (2010): Encuesta de Presupuestos Familiares 2006. Base de datos INEBase.

6. $\quad$ Perles, J.F. (2006): “Análisis del impacto económico de eventos: una aplicación a fiestas populares de proyección turística", Cuadernos de Turismo, 17, 147-166.

7. Ramírez, J.M.; Ordaz, J.A. and Rueda, J.M. (2007): "Evaluación del impacto económico y social de la celebración de grandes eventos deportivos a nivel local: el caso del Campeonato de Tenis Femenino de la ITF en Sevilla en 2006", Revista de Métodos Cuantitativos para la Economía y la Empresa, 1, 20-39.

8. Seaman, B. (2003): "Economic impact of the arts". In Towse, R. (2003): A handbook of cultural economics, cap. 27 , pp. 224-231.

9. Semana de Música Religiosa (2009): Dosier de prensa $48^{a}$ edición, (Available from: www.smrcuenca.es).

10. Semana de Música Religiosa (2009): Datos de asistentes al festival. (Unpublished document).

11. Semana de Música Religiosa (2009): Claves de la 48 SMR de Cuenca. (Available from: www.smrcuenca.es).

12. Fundación Provincial de Cultura. Diputación de Cádiz (2008): Impacto económico del XI Festival de Flamenco de Jerez.

13. Instituto Valenciano de Investigaciones Económicas (2007): Impacto económico de la 32 ${ }^{a}$ America's Cup Valencia 2007. 
NOTES 